\title{
Recent advances in the pathology of pituitary adenomas
}

\author{
AYODEJI, S. ${ }^{1 *}$, EFFIONG, A. ${ }^{1}$ and ADEFOLARIN, M. $^{2}$ \\ ${ }^{1}$ Department of Pathology, University College Hospital, Queen Elizabeth II road, PMB 5116 Agodi, Ibadan, Oyo \\ state, Nigeria, West Africa \\ ${ }^{2}$ Department of Neurological Surgery, University College Hospital, Queen Elizabeth II road, PMB 5116 Agodi, \\ Ibadan, Oyo state, Nigeria, West Africa \\ *E-mail: ayodejisalami@gmail.com
}

\begin{abstract}
Introduction: Pituitary adenomas are the third most common intracranial tumours. The 2004 WHO classification of pituitary adenomas has recommended the use of immunohistochemistry, electron microscopy and molecular techniques along with clinical and morphological evaluation in making a diagnosis. This review examines the subtypes of pituitary adenomas seen using the different diagnostic techniques. Materials and Methods: A comprehensive search of literature as well as an online search of databases was made. Results: The classification and molecular properties of the different subclasses are highlighted in this review. Pituitary adenomas are among the most frequent intracranial tumours and can present with over-expression of the hormones normally produced by the pituitary gland or pressure symptoms from the tumour. Pituitary adenomas are clonal tumours and often show over-expression of tumour suppressor genes which can sometimes be familial. Molecular studies have shown expression of common genes that can be employed to group pituitary adenomas based on their histogenetic origin. These genetic properties can be helpful in delineating those tumours which do not show clear cut lineage. This is particularly useful in the assessment of silent and plurihormonal adenomas. Several subclasses exist and the presentation may be different depending on the particular hormone produced. The prolactinomas are the commonest type followed by the silent adenomas with Gonadotroph and TSH producing adenomas constituting the rare types. Conclusion. Pituitary carcinomas are rare tumours diagnosed only in the presence of metastatic deposits in other tissues.
\end{abstract}

Keywords: pituitary adenoma, oncogenes, classification, immunohistochemistry.

\section{Introduction - Anatomy and Physiology of the Pituitary Gland}

The pituitary gland is a small ovoid structure weighing about $0.5 \mathrm{~g}$ and located in the pituitary fossa, a small depression in the cranial surface of the sphenoid bone. It is attached superiorly to the tuber cinereum of the hypothalamus by the infundibulum, which is surrounded by a vascular plexus formed by the hypophyseal vessels. The gland is covered superiorly by a circular diaphragma sellae of dura mater which separates the anterior part of the gland from the optic chiasm. The pituitary is bounded bilaterally by the cavernous sinuses and their contents. Inferiorly, it is separated from the floor of the pituitary fossa by a venous sinus that communicates with the circular sinus. Antero-inferiorly, it is bounded by the sphenoid sinus (ONTJES and NEY, 1976; LOPES, PERNICONE, SCHEITHAUER et al., 2007).

The pituitary gland is composed of two parts, the adenohypophysis (anterior pituitary) and the neurohypophysis (posterior pituitary), which differ both embryologically and functionally. The anterior pituitary develops from Rathke's pouch which is an embryonic invagination of the ectodermal pharyngeal epithelium, arising just rostral to the superior attachment of the buccopharyngeal membrane. The posterior pituitary develops from a neural tissue down- growth of the hypothalamus. Between these is a small, relatively avascular zone called the pars intermedia (intermediate zone) which is almost completely absent in humans (SCHEITHAUER, 2003; NOSÉ and HEDLEY-WHITE, 2004).
The two hormones of the posterior pituitary (oxytocin and vasopressin) are synthesised in the supraoptic and paraventricular nuclei of the hypothalamus and are stored and released by the neurohypophysis. The anterior pituitary produces six hormones secreted by five different groups of cells, which include lactotrophs, somatotrophs, corticotrophs, gonadotrophs and thyrotrophs (OSAMURA, KAJIYA, TAKEI et al., 2008; ONTJES and NEY, 1976). Although the gland appears homogenous grossly, microscopically there is a localization of the various cell types within the adenohypophysis with division of the gland into three parts (LOPES, PERNICONE, SCHEITHAUER et al., 2007; SCHEITHAUER, 2003). The adrenocorticotroph and thyrotroph cells are localized mainly at the central part of the gland, otherwise called the mucoid wedge named due to the abundance of basophilic PAS positive cells in that area. The growth hormone and prolactin producing cells are found in the lateral wings with the somatotrophs lying anteriorly and the prolactinomas posteriorly. The gonadotrophs are diffusely scattered within the other cell types (LOPES, PERNICONE, SCHEITHAUER et al., 2007; SCHEITHAUER, 2003) (Figures 1 and 2).

The pituitary gland controls most of the other endocrine glands in the body via the effects of the hormones secreted in the anterior pituitary. Physiological events in the human body, such as pregnancy may cause transient hyperplasia which 


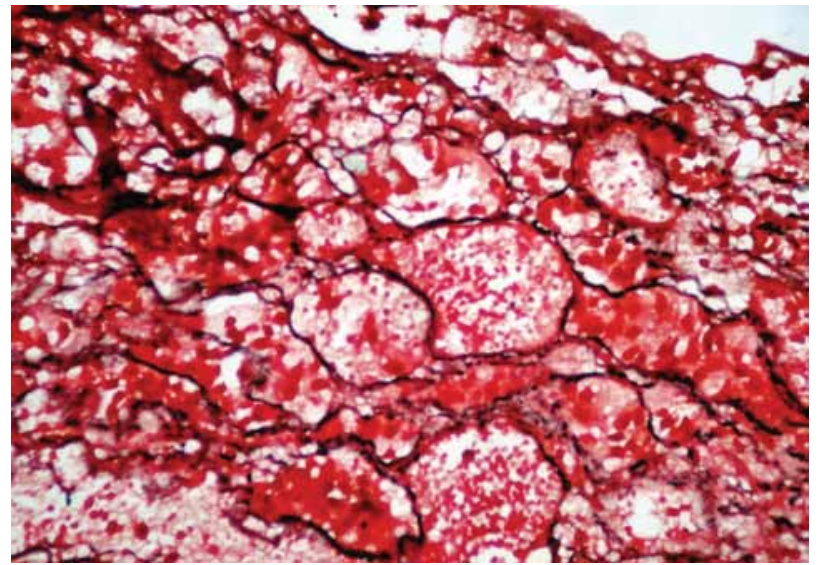

Figure 1. Normal acinar architecture of the pituitary gland. Reticulin stain.

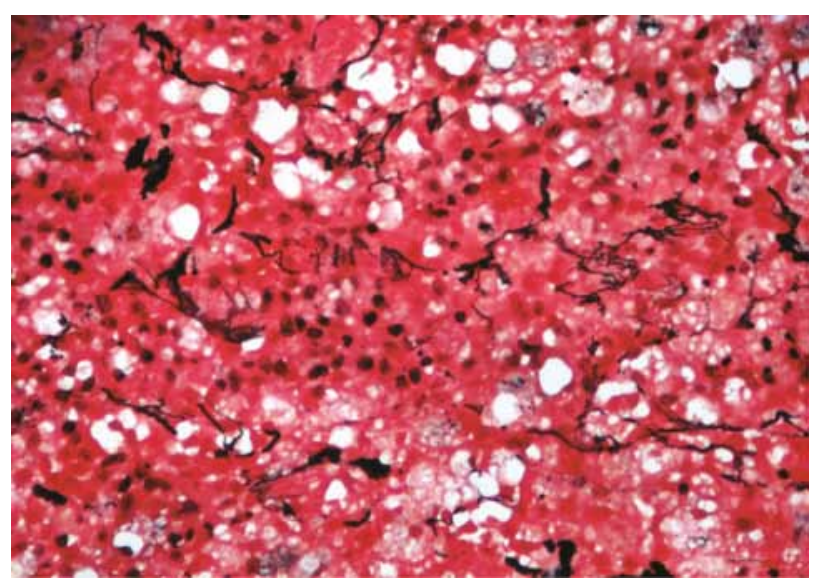

Figure 2. Disruption of the acinar architecture in a Pituitary adenoma. Reticulin stain.

may be confused with a pathological lesion (AL-BRAHIM and ASA, 2006).

\section{Clinical Manifestations}

Although pituitary adenomas occur most commonly in adults, they can also occur in children. Pituitary adenomas manifest clinically as insufficiency syndromes due to hyposecretion of some hormones, resulting from compression of the residual normal pituitary tissue by the tumour, or as hypersecretion due to excessive production of hormones by the neoplastic cells. Hormonal deficiencies resulting from pituitary adenomas usually follow a sequential loss in the order of $\mathrm{GH}, \mathrm{LH} / \mathrm{FSH}$, TSH, ACTH, and prolactin (KUNWAR and WILSON, 1999). In children, growth retardation and short stature are common clinical effects of pituitary adenomas with the exception of growth hormone releasing tumours (KUNWAR and WILSON, 1999). Other clinical symptoms seen with pituitary adenomas depend on the hormone produced by the tumour. Growth hormone hypersecretion in children manifests as gigantism while in adults acromegalic facies are seen in patients. Hypogonadism and menstrual irregularities are also seen (IRONSIDE, 2003; KUNWAR and WILSON, 1999; LAFFERTY and CHROUSOS, 1999; SINGH and
AGGARWAL, 2005). Hypersecretion of prolactin presents with gynaecomastia and hypogonadism in males and amenorrhea in females (KUNWAR and WILSON, 1999; LAFFERTY and CHROUSOS, 1999; SINGH and AGGARWAL, 2005). Hypersecretion of prolactin can also result from mass pressure effect on the pituitary stalk which cuts off the inhibitory effect of dopamine on mammotrophs with resulting unregulated secretion (CAWICH, CRANDON, HARDING et al., 2008). Hypersecretion of adrenocorticotrophic hormone usually present as Cushing's disease with hypertension, growth retardation, diabetes and abdominal striae (KUNWAR and WILSON, 1999; LAFFERTY and CHROUSOS, 1999; SINGH and AGGARWAL, 2005, CAWICH, CRANDON, HARDING et al., 2008). Gonadotroph adenomas may present with sexual precocity in children and menstrual irregularities and hypogonadism in adults (KUNWAR and WILSON, 1999; LAFFERTY and CHROUSOS, 1999; SINGH and AGGARWAL, 2005; CAWICH, CRANDON, HARDING et al., 2008). Thyroid dysfunction may also occur in thyrotroph adenomas and can either result in hyposecretion or hypersecretion with the presentation being myxoedema or hyperthyroidism respectively (CAWICH, CRANDON, HARDING et al., 2008).

Mass pressure effects on neighbouring structures may also be seen. Compression of the optic chiasma is the commonest, usually manifesting with various visual defects such as bitemporal hemianopia, bitemporal quadrantanopia, impaired visual acuity and there may be optic nerve atrophy (CAWICH, CRANDON, HARDING et al., 2008; LLOYD, KOVACS, YOUNG JUNIOR, et al., 2004). Compression of the cavernous sinus often causes cranial nerve palsies from dysfunction of the third, fourth and sixth nerves and the patient presents with ophthalmoplegia, diplopia and ptosis. There may also be loss of sensation on the face from affectation of the ophthalmic and maxillary branches of the trigeminal nerve (LEVY, 2004; MELMED, 2008). The neighbouring hypothalamus and the posterior pituitary may also be compressed by the neoplasm with destruction of the supraoptic and paraventricular nuclei resulting in diabetes insipidus (MELMED, 2008). Pituitary apoplexy can occur from compression of the pituitary stalk with interruption of blood flow through the portal system of arteries supplying the pituitary with resultant infarction of the gland (EZZAT and ASA, 2006; IRONSIDE, 2003; LLOYD, KOVACS, YOUNG JUNIOR, et al., 2004).

Pituitary adenomas may also erode through the underlying sphenoid bone resulting in communication with the pharynx. This causes CSF rhinorrhoea and ascending infection into the intracranial compartment (LEVY, 2004; MELMED, 2008). The commonest non-specific mode of presentation includes headaches and photophobia from raised intracranial pressure (LEVY, 2004; MELMED, 2008).

\section{Epidemiology}

Costello in 1936 gave the prevalence of pituitary adenoma as $22.5 \%$ based on a study of 1000 pituitary glands obtained from autopsies done at the Mayo clinic (COSTELLO, 1936; DALY, TICHOMIROWA, BECKERS et al., 2009). Ezzat, Asa, Couldwell et al. (2004) conducted a systematic review of eight autopsy series and five radiological studies in the United States, Europe and Asia. The radiological studies used either magnetic resonance imaging or high-resolution computed tomography. Their review showed wide variation in prevalence 
ranging from $1 \%$ to $40 \%$ from the different studies but the overall estimated prevalence from the autopsy studies was $14 \%$ while the radiological studies showed $22.5 \%$ prevalence (IRONSIDE, 2003; OSAMURA, KAJIYA, TAKEI, et al., 2008; DALY, TICHOMIROWA and BECKERS, 2009; EZZAT, ASA, COULDWELL et al., 2004; VANDEVA, JAFFRAIN-REA, DALY et al., 2010). However cancer registry studies from Europe and the United States of America indicate a prevalence of 5 to 20\% (AL-BRAHIM and ASA, 2006; ASA and EZZAT, 1998; DALY, TICHOMIROWA and BECKERS, 2009).

A lower prevalence of pituitary adenoma was shown in the Asian population according to the study by Wen-Qing, Shi-Ju, Qing-Sheng et al. (1982). They obtained a prevalence of $9.52 \%$ in a study incorporating twelve Chinese regions (WEN-QING, SHI-JU, QING-SHENG et al., 1982). Pituitary adenomas are less common in children and studies have shown a prevalence of $2.7 \%$ of all supratentorial tumours in childhood (LAFFERTY and CHROUSOS, 1999). The prevalence of pituitary adenoma in an African population ranged from $16.8 \%$ to $21 \%$ in studies from different hospital units in Nigeria (IGUN, 2001; IDOWU, AKANG and MALOMO, 2007; OLASODE, SHOKUNBI and AGHADIUNO, 2000; OHAEGBULAM, SADDEQI and IKERIONWU, 1980).

There is a slight male preponderance in studies done in adult patients with a male to female ratio of 1.4:1 (IDOWU, AKANG and MALOMO et al., 2007). It is known to occur between ages 2-70 years, but the peak period of occurrence is between 30-60 years (SCHEITHAUER, 2003; DALY, TICHOMIROWA and BECKERS, 2009; KOVACS, HORVATH and VIDAL, 2001). Prolactinomas are the most commonly seen of the adenomas with a frequency of $42 \%$ in some studies (DALY, TICHOMIROWA and BECKERS, 2009; EZZAT et al, 2004). This was also the case in the paediatric population with an incidence of 53\% (LAFFERTY AND CHROUSOS, 1999). In the comparison by Ezzat et al. of three different autopsy series, non-secreting adenomas constituted the next most prevalent group of about $14.7 \%$ while somatotrophinomas had a prevalence of $13.2 \%$ (EZZAT, ASA, COULDWELL et al., 2004).

\section{Pathogenesis}

Majority of pituitary adenomas (about 95\%) are sporadic in nature (ASA and EZZAT, 1998; FARELL, 2006). About $5 \%$ of pituitary adenomas occur as part of tumour syndromes mainly MEN 1, Carney's complex and familial isolated pituitary adenomas each of which has different genetic abnormalities (ASA and EZZAT, 1998; IRONSIDE, 2003; MAITRA, 2010). At present there are two main theories regarding the tumourigenesis of pituitary adenoma. These include the hormonal stimulation theory and the intrinsic pituitary cellular defect (EZZAT and ASA, 2006; LLOYD, KOVACS, YOUNG JUNIOR, et al., 2004; HINTON and ASA, 2009). The hormonal stimulation theory has been supported by several observations, one of which is the hyperplasia with occasional adenoma occurring in situations characterized by exogenous hypothalamic hormonal stimulation (IRONSIDE, 2003; ASA and EZZAT, 1998; DALY, TICHOMIROWA and BECKERS, 2009). There have been reports of somatotroph adenomas arising from excessive hyperstimulation of the anterior hypophyseal cells by growth hormone releasing hormone. This has been either by ectopic production outside of the hypothalamus and in some very rare cases by local production of the hormone within the hypophyseal cells (ASA and EZZAT, 1998). Corticotroph and thyrotroph adenomas have also been associated with hyperplasia resulting from exogenous stimulation of the anterior pituitary (ASA and EZZAT, 1998).

Reduced feedback suppression of the pituitary hormones by target organs with resulting hyperplasia has been linked in rare instances with the development of pituitary tumours (ASA and EZZAT, 1998). Lactotroph hyperplasia resulted in mice following the knock out of their dopamine receptors which function in the inhibition of lactotroph secretion. Molecular studies are however yet to show any abnormalities in the dopamine receptors of humans with lactotroph adenomas (ASA and EZZAT, 1998). It is known that somatostatin receptors usually found in somatomammotrophs tend to show reduced expression in somatotroph tumours particularly those with invasive characteristics and reduced response to Octreotide, a somatostatin inhibitor. Studies have shown multiple mechanisms of stimulation of pituitary cells by somatostatin with resultant hyperplasia (ASA and EZZAT, 1998). Corticotroph and thyrotroph adenomas have also been documented to arise on a background of reduced inhibitory feedback from target cells. This is thought to be the explanation for Nelson syndrome which usually results following adrenalectomy for Cushing's disease (ASA and EZZAT, 1998).

One of the main factors militating against the hormonal theory is the absence of background hyperplasia in most pituitary adenoma which should have been the case if this is a precursor event as was previously thought (EZZAT and ASA, 2006; IRONSIDE, 2003; ASA and EZZAT, 1998). It has been shown that most pituitary glands do not undergo adenomatous changes even after prolonged and excessive hormonal stimulation and in adenomas that are successfully resected there is low incidence of recurrence (EZZAT and ASA, 2006; IRONSIDE, 2003).

Several growth factors have been shown to have significant effects on pituitary tumour growth although many of the receptors that are commonly seen in other neoplasms have not been implicated (EZZAT and ASA, 2006; IRONSIDE, 2003). Transforming growth factor beta mutations have been found in gonadotroph adenomas (EZZAT and ASA, 2006). This growth factor functions via activin receptors which normally activates secretion by the cells and is modulated by follistatin. Some of these neoplastic cells have been found to harbour follistatin receptor mutations (ASA and EZZAT, 1998; EZZAT, ASA, COULDWELL et al., 2004). Another growth factor implicated in pituitary tumourigenesis is a truncated kinase containing variant of fibroblast growth factor receptor which has recently been isolated and shown to cause neoplastic transformation of pituitary glands in mice (ASA and EZZAT, 1998; EZZAT, ASA, COULDWELL et al., 2004).

The molecular theory of pituitary tumourigenesis is based on monoclonality of the tumour cells (EZZAT and ASA, 2006; IRONSIDE, 2003). Many target genes have been implicated in the pathogenesis of sporadic adenomas although few have actually been found to have actual roles in the aetiology of the tumour (ASA and EZZAT, 1998; EZZAT, ASA, COULDWELL et al., 2004; FARRELL, 2006). Most of the oncogenes usually implicated in common malignancies have rarely been implicated in pituitary tumours (EZZAT et al, 2004). Mutations of the retinoblastoma and p53 genes have 
not been found in pituitary adenomas (ASA and EZZAT, 1998; EZZAT, ASA, COULDWELL et al., 2004; FARRELL, 2006) The most important oncogene involved in the sporadic pituitary tumourigenesis is gsp, which encodes the Gsa subunit - a stimulatory guanine-binding protein that regulates hypothalamic $\mathrm{GH}$ releasing hormone (GHRH) effects in somatotrophs (ASA and EZZAT, 1998; EZZAT, ASA, COULDWELL et al., 2004; FARRELL, 2006). Mutations in gsp have been most closely associated with somatotrophinomas, and they are found to occur in up to $40 \%$ of these tumours. Point mutation at codon 201 or 227 causes constitutive activation of Gsa by inhibiting guanosine triphosphate (GTP) hydrolysis (IRONSIDE, 2003; ASA and EZZAT, 1998; FARRELL, 2006).

Mutations of pl6 have been found to occur in about $80 \%$ of pituitary adenomas although to the extent to which these various changes contribute to tumourigenesis is not known (IRONSIDE, 2003). Recently a new oncogene, pituitary tumour transforming gene (PTTGl), has been found to be expressed in most pituitary adenomas but this is not seen in the normal pituitary gland. This oncogene belongs to a family of genes that regulate chromatid separation during mitosis. It is thought that over-expression of PTTG may contribute to aneuploidy of adenoma cells (IRONSIDE, 2003; ASA and EZZAT, 1998; FARRELL, 2006; LANIA, MANTOVANI and SPADA, 2003; SALEHI, KOVACS, SCHEITHAUER et al., 2010). Many neoplastic pituitary tumour cells have been found to express a novel protein known as $\mathrm{N}$ terminally truncated isoform of FGF receptor-4, ptd-FGFR4 (LLOYDS, KOVACS, YOUNG JUNIOR et al., 2004). This protein is also not found in normal pituitary glands and induces adenoma in transgenic mice. Although it is implicated in pituitary tumourigenesis, its contribution to tumourigenesis is a subject of ongoing research.

Many other oncogenes and receptors have been implicated in the pathogenesis of pituitary adenomas, which include protein kinase $\mathrm{C}$ isoforms, which are over-expressed in some pituitary tumours (EZZAT, ASA, COULDWELL et al., 2004; LANIA, MANTOVANI and SPADA, 2003). GADD45 gene under-expression has been noted in a significant number of pituitary adenomas (EZZAT and ASA, 2006; FARRELL, 2006). GADD 45 is a growth arrest and DNA damage inducible gene which functions as a tumour suppressor gene and is silenced by promoter methylation. In the same vein, MEG3 under-expression has been found in non-functioning pituitary tumours (EZZAT and ASA, 2006; LANIA, MANTOVANI and SPADA, 2003; FARRELL, 2006). Although the functional role of this gene is not known at present but the functional homolog of it, MEG3a inhibits cell growth (EZZAT and ASA, 2006). Over-expression of high mobility group A non-histone chromosomal proteins have been seen in some pituitary tumours. These proteins are usually found in rapidly proliferating embryonic tissues and in tumours (VANDEVA, JAFFRAIN-REA, DALY et al., 2010; LANIA, MANTOVANI and SPADA, 2003). The extent to which all the different genes and their products influence tumourigenesis is yet to be fully elucidated.

\section{Familial Pituitary Adenomas}

Several genetic disorders include pituitary adenomas in the syndrome complex. These include types 1 and 4 multiple endocrine neoplasia, Carney's complex and familial isolated pituitary adenomas (EZZAT and ASA, 2006; HEMMINKI, FÖRSTI and JI, 2007; FARRELL, 2006).

\subsection{Multiple endocrine neoplasia (Men 1):}

This syndrome is an autosomal dominant genetic disorder resulting from mutations in $M E N 1$, which normally functions as a tumour suppressor gene located on chromosome $11 \mathrm{q} 13$, and controls genome stability by repression of telomerase activity via telomerase reverse transcriptase. The gene indirectly controls the promoter region of several endocrine and non-endocrine genes (ASA and EZZAT, 1998; VANDEVA, JAFFRAIN-REA, DALY et al., 2010; HEMMINKI, FÖRSTI and JI, 2007). Mutations of this gene have not been described in sporadic tumours, which indicate that it does not contribute to tumourigenesis in non-familial tumours (ASA and EZZAT, 1998; LANIA, MANTOVANI and SPADA, 2003; HEMMINKI, FÖRSTI and JI, 2007). The syndrome comprises a predisposition to parathyroid hyperplasia, pancreatic endocrine tumours and pituitary adenomas. Up to $40 \%$ of affected individuals harbour pituitary tumours, and these comprise prolactinomas (60\%), $\mathrm{GH}$-secreting adenomas (20\%), ACTH-secreting adenomas $(<10 \%)$, and non-functional adenomas $(<10 \%)$ (HEMMINKI, FÖRSTI and JI, 2007). Although this syndrome usually is seen in a familial setting, it also occasionally occurs in sporadic cases (LANIA, MANTOVANI and SPADA, 2003; HEMMINKI, FÖRSTI and JI, 2007). The mutations seen in the gene can be nonsense or frame-shift, which often occurs due to deletions in the intronic segments of the gene (VANDEVA, JAFFRAINREA, DALY et al., 2010). About 500 different mutations have been described with this syndrome and these show different phenotypic manifestation (VANDEVA, JAFFRAIN-REA, DALY et al., 2010).

The pituitary adenomas seen in MEN 1 are usually more aggressive than in sporadic tumours and often show compressive effects (HEMMINKI, FÖRSTI and JI, 2007). Prolactinomas predominate in the tumours seen in this syndrome and are usually accompanied by excessive growth hormone secretion with resultant acromegaly (HEMMINKI, FÖRSTI and JI, 2007). Unlike sporadic tumours that often manifest as microadenomas, macroadenomas are most commonly seen with MEN 1 and these tumours often show poor response to dopamine agonists (HEMMINKI, FÖRSTI and JI, 2007).

Recently some groups of families, constituting about $20 \%$ of MEN 1 cases which showed phenotypic appearances of MEN 1 were found not to show the typical genetic mutations of chromosome 11. Further studies showed mutations in CDKNlgene coding for p27 (HEMMINKI, FÖRSTI and JI, 2007; VANDEVA, JAFFRAIN-REA, DALY et al., 2010) on chromosome 12 and this group has been described as MEN 4. Patients with this syndrome often present with acromegaly, primary hyperparathyroidism, renal angiomyolipoma, small cell neuroendocrine tumour and Cushing's disease.

\subsection{Carney's complex}

Carney's complex is an autosomal dominant disorder characterised by somatomammotrophic adenomas and elevated IGF- 1 with acromegalic facies (HEMMINKI, FÖRSTI and JI, 2007, BOIKOS AND STRATAKIS, 2007). Other components of the syndrome include lentigines, myxomas, Schwann cell tumours, primary pigmented nodular adrenocortical disease (PPNAD), thyroid tumours and nodules, testicular tumours (large cell calcifying Sertoli cell tumour (LCCSCT), Leydig cell 
tumours (HEMMINKI, FÖRSTI and JI, 2007; VANDEVA, JAFFRAIN-REA, DALY et al., 2010).

The protein kinase 1 alpha regulatory subunit gene (PRKARIA) is associated with this syndrome complex in 60\% of cases (HEMMINKI, FÖRSTI and JI, 2007; BOIKOS and STRATAKIS, 2007). The syndrome is rare with the mutated tumour suppressor gene located on chromosome 17q22-24 (BOIKOS and STRATAKIS, 2007). The gene functions in regulating cyclic AMP and loss of the gene results in unregulated activity of the enzyme. Another gene locus associated with the syndrome is chromosome 2pl6 although the relationship of this gene is yet to be fully elucidated (VANDEVA, JAFFRAINREA, DALY et al., 2010; BOIKOS and STRATAKIS, 2007).

\subsection{Familial isolated pituitary adenoma (fipa)}

Pituitary adenomas have been found to arise in certain families in which members can show homogeneous or heterogeneous forms of presentation (DALY, TICHOMIROWA and BECKERS, 2009; HEMMINKI, FÖRSTI and JI, 2007). Prolactinomas (41\%) have the highest rate of occurrence followed by the somatotroph adenomas (30\%) (DALY, TICHOMIROWA and BECKERS, 2009; HEMMINKI, FÖRSTI and JI, 2007; BOIKOS and STRATAKIS, 2007). The tumours are not more aggressive compared to the general population but heterogeneous prolactinomas and non-secretory adenomas occurring in familial isolated adenomas are more aggressive (BOIKOS and STRATAKIS, 2007). The tumours tend to occur at a younger age than the sporadic component and often manifests earlier in the siblings of affected patients (DALY, TICHOMIROWA and BECKERS, 2009; HEMMINKI, FÖRSTI and JI, 2007).

The gene affected in FIPA has been localized to chromosome $1 \mathrm{lq} 13.3$ which codes for aryl hydrocarbon receptor interacting protein (AIP). This protein product interacts with different gene products including AHR, a dimer of heat shock protein 90 co-chaperone p23 (HEMMINKI, FÖRSTI and JI, 2007). AHR is known to function in transcription of xenobiotic enzymes but it also interacts with other genes involved in cell growth and apoptosis. Nonsense and frame shift mutations have been documented in many cases with some showing premature stop codons (VANDEVA, JAFFRAIN-REA, DALY et al., 2010; FARRELL, 2006). Interestingly a minority of sporadic tumours also show mutations on the AIP gene (VANDEVA, JAFFRAIN-REA, DALY et al., 2010; FARRELL, 2006).

\section{Classification of Pituitary Adenomas}

Several different classifications of pituitary adenomas have evolved over time. Some of these have been clinical while others are pathological. Clinically pituitary adenomas are classified based on the functional and endocrine activity (IRONSIDE, 2003; KOVACS, HORVATH and VIDAL, 2001). Most tumours secrete hormones in excess while others are nonsecreting. Another classification method used particularly by the surgeons is based on the sizes of the tumour and the degree of invasion into surrounding tissues (IRONSIDE, 2003). This is accessed via neuroradiological imaging and several classification systems were based on this method. The Hardy and Verzina classification has been most commonly used and grades adenomas from 0 - IV based on size, location within or outside the sella turcica, and bony erosion (IRONSIDE, 2003; BECKERS and DALY, 2007). Tumours that are less than $10 \mathrm{~mm}$ in size are classified as microadenomas while those that are more than $10 \mathrm{~mm}$ are macroadenomas. The microadenomas are graded as 0 - I with tumours that are intrasellar with no affectation of the sella and those that do not erode the underlying bone but show focal enlargement of the sella. The grades II to IV adenomas are tumours that are more than $10 \mathrm{~mm}$ in size and are macroadenomas. The grade II tumours also do not show bony erosion but there is diffuse enlargement of the gland. Grade III and IV tumours both show erosion of the bony sella but there is involvement of extrasellar structures in grade IV tumours (IRONSIDE, 2003; HINTON and ASA, 2009).

The traditional pathological classification method was based on staining with Haematoxylin and Eosin in which the tumours are placed into three groups namely the chromophobes, acidophils and basophils based on their characteristic tinctorial affinities (ASA and EZZAT, 1998; LLOYD, KOVACS, YOUNG JUNIOR et al., 2004; REMICK, WOOD, CANN et al., 2006). The chromophobes usually do not stain, as they do not contain granules. The acidophils and basophils usually stain with acidic and basophilic dyes. This has been largely abandoned as these groups of tumours have been found to overlap in their functional activity (LLOYD, KOVACS, YOUNG JUNIOR et al., 2004). The latest (2004) classification of pituitary adenomas by the World Health Organization is based on the immunohistochemical staining of the tumour, using antibodies against secreted hormones, and the tumour ultrastructural properties. Many of the non-functional tumours have also been discovered to produce these hormones and take up the stains of the corresponding hormone (LLOYD, KOVACS, YOUNG JUNIOR et al., 2004; KOVACS, HORVATH and VIDAL, 2001). Some adenomas, which produce sparse granules, are further identified by the use of other antibodies such as cytokeratins (IRONSIDE, 2003; HINTON and ASA, 2009). Ultrastructural classification is needed to identify some rare adenomas that cannot be characterized by immunohistochemistry. Some adenomas are also multihormonal and display the ultrastructural features of the different cell types that are represented in the tumour (ASA and EZZAT, 1998).

Several other classifications of pituitary adenomas have been proposed. One of such proposed classifications is that of Asa which group pituitary adenomas into families based on their embryogenesis. These different subgroups have different properties that are useful in arriving at management decisions. Kovacs et al. have also proposed a five tiered clinicopathological classification which aims to correlate endocrine manifestations, aggressiveness of the tumour and morphological phenotypes (KOVACS, HORVATH and VIDAL, 2001; HINTON and ASA, 2009).

\subsection{Growth hormone, prolactin and thyrotropin family}

Somatomamotroph adenomas: Growth hormone producing tumours represent one of the most common subgroup of pituitary adenomas and usually produce one of two types of clinical phenotypes depending on the age at presentation. In the young, these types of tumours produce gigantism since the epiphyses are yet to fuse while in the adult they produce acromegaly (OSAMURA, KAJIYA, TAKEI et al., 2008). Recent studies have linked acromegaly with increased incidence of cancer of the breast, colon, thymic tumours and meningiomas 
(MELMED, 2001). This is believed to be due to the effect of insulin-like growth factor 1 , which is known to interact with growth hormone and increase cell proliferation. Although the molecule does not initiate tumourigenesis, it is believed to function as a promoter.

Growth hormone adenomas can be classified into five distinct adenomas, which include both pure and plurihormonal growth hormone producing tumours. The five groups include densely and sparsely granulated adenomas that are pure growth hormone producing tumours. The other growth hormone adenomas are plurihormonal and include mammosomatotroph adenomas, mixed somatotroph-lactotroph adenomas, and acidophil stem cell adenomas (SAEGER, LÜDECKE, BUCHFELDER et al., 2007). Most of the somatotroph adenomas are plurihormonal with about $80 \%$ also producing prolactin and a smaller percentage also secreting somatostatin. Generally, the sparsely granulated and silent somatotroph adenomas are more aggressive with infiltration of neighbouring structures (OSAMURA, KAJIYA, TAKEI et al., 2008).

Characteristically some somatotroph adenomas display fibrous bodies, which are perinuclear globules of keratin usually consisting of intermediate filaments. Some somatotroph adenomas also show amyloid deposits around the tumour cells which often stain weakly for growth hormone (OSAMURA, KAJIYA, TAKEI et al., 2008; HINTON and ASA, 2009).

Molecular studies have shown overexpression of pit-1 by somatotroph cells. This gene is normally functional in the regulation of the growth hormone, prolactin and thyroid stimulating hormone-producing cells. Recent studies have shown that the pit-1 gene also functions as a cell cycle suppressor (MELMED, 2008). The MEN 1 gene, which is located on chromosome 11 , is also frequently associated with prolactinomas and somatotroph adenomas. About $40 \%$ of somatotrophs show constitutive activation of adenylate cyclase due to somatic mutations of the Gs $\alpha$ subunit (OSAMURA, KAJIYA, TAKEI et al., 2008).

Lactotroph adenomas: prolactinomas are the most common of the pituitary adenomas constituting about $40 \%$ of all pituitary adenomas (KOVACS, HORVATH, STEFANEANU et al., 1998). They are usually monohormonal with production of only prolactin and manifest clinically as hyperprolactinaemia. They are more common in women with a male to female ratio of $1: 10$. The clinical effects of these tumours include infertility in women, sexual disturbances and gynaecomastia in men (LLOYD, KOVACS, YOUNG JUNIOR et al., 2004; HINTON and ASA, 2009).

The neoplastic cells are of three types, the sparsely granulated (the most commonly occurring variant), the densely granulated and the rare acidophil stem cell adenomas. Histologically the tumours often show calcospherites within the stroma and they all exhibit the phenomenon of misplaced exocytosis, which is the secretion of their granules into the lateral space (OSAMURA, KAJIYA, TAKEI et al., 2008; HINTON and ASA, 2009) (Figure 3). There is occasional production of amyloid within the tumour cells. The acidophil stem cell adenomas show a different phenotypic manifestation as with secretion of growth hormone and acromegalic facies in some patients (HINTON and ASA, 2009). These cells also show oncocytic appearance and perinuclear keratin globules similar to what is seen in somatotroph adenomas.

Lactotroph adenomas are also among the neoplasms seen in multiple endocrine tumours, which results from mutations in

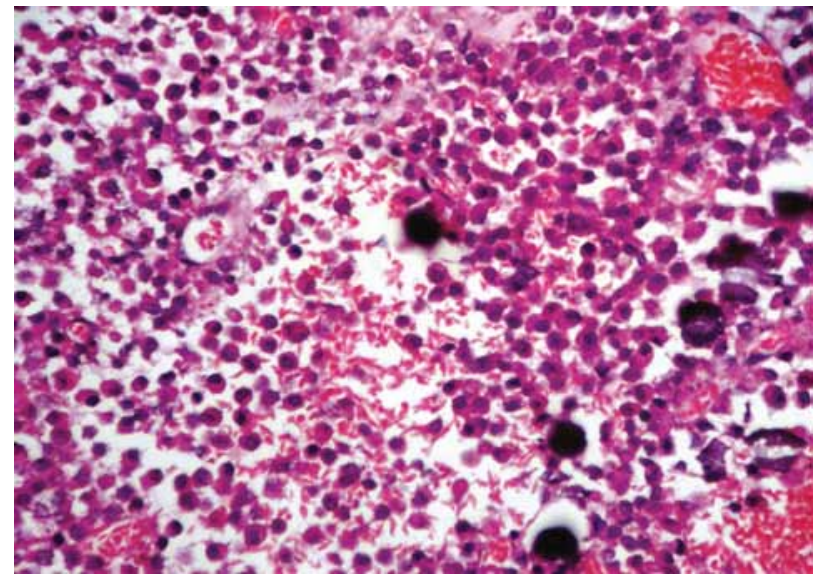

Figure 3. Calcospherites in a Pituitary adenoma. $\mathrm{H}$ and $\mathrm{E}$.

the Menin gene. Prolactinomas are positive for the pit-1 gene, which is seen in growth hormone adenomas (OSAMURA, KAJIYA, TAKEI et al., 2008). Oestrogen receptors are also over-expressed in prolactinomas. These tumours are highly responsive to dopamine agonists such as bromocriptine and in many centres a few cases require surgical intervention (KUNWAR and WILSON, 1999). Prolactinomas have been shown to result from deficient delivery of dopamine to the lactotroph cells. Recent research on gene therapy using transfected adenoviruses to transfer genes for the production of dopamine into adenomas shows a significant reduction in prolactin production (EZZAT and ASA, 2006).

Thyrotroph adenomas: Thyrotroph adenomas occur infrequently and constitute about $1 \%$ of all adenomas (MAITRA, 2010; HINTON and ASA, 2009). They are often plurihormonal with production of prolactin and growth hormone (OSAMURA, KAJIYA, TAKEI et al., 2008; SAEGER, LÜDECKE, BUCHFELDER et al., 2007). Chronic excess production often results in diffuse goitre with hyperthyroidism but in some cases, patients are euthyroid. Thyrotrophs share a common progenitor cell origin with lactotrophs and somatotrophs and express pit-1 and GATA 1 gene (OSAMURA, KAJIYA, TAKEI et al., 2008; HINTON and ASA, 2009). There is associated immunoreactivity for $\beta$ and $\alpha$ TSH subunits (OSAMURA, KAJIYA, TAKEI et al., 2008; HINTON and ASA, 2009).

These tumours are usually macroadenomas with invasion of neighbouring structures. They are chromophobic with stromal fibrosis and psammoma bodies (OSAMURA, KAJIYA, TAKEI et al., 2008; HINTON and ASA, 2009; SAEGER, LÜDECKE, BUCHFELDER et al., 2007). Immunohistochemistry often shows staining for prolactin, growth hormone and thyrotrophin indicating their plurihormonal nature.

\subsection{Adrenocorticotrophin family}

Corticotroph adenomas: Corticotroph tumours constitute about $10-15 \%$ of all pituitary adenomas and often present as microadenomas (OSAMURA, KAJIYA, TAKEI et al., 2008; HINTON and ASA, 2009; SAEGER, LÜDECKE, BUCHFELDER et al., 2007). The transcription factor neuroDl and Tpit are usually expressed in the tumours and they sometimes show immunoreactivity for pro-opiomelanocortin, alpha-melanocyte stimulating hormone and $\beta$-endorphin (OSAMURA, KAJIYA, TAKEI et al., 2008; HINTON and 
ASA, 2009). In actively secreting tumours, there is also strong staining for low molecular weight cytokeratin in peritumoural corticotroph cells, which accumulate cytoplasmic intermediate filaments because of the hypercortisolism. This result in the Crooke's hyaline change and the cells are called Crooke's cells (OSAMURA, KAJIYA, TAKEI et al., 2008; HINTON and ASA, 2009; SAEGER, LÜDECKE, BUCHFELDER et al., 2007).

Corticotrophs are monohormonal and are usually microadenomas. They are commonly associated with Cushing syndrome and occasionally with Nelson syndrome. This adenoma variant has several subtypes, which include the densely and sparsely granulated subtypes and the rare Crooke's cell adenoma as well as the inactive corticotroph adenomas. The densely granulated subtypes are often basophilic while the sparsely granulated types are chromophobic. Both stain positive to PAS due to the carbohydrate component in pro-opiomelanocortin, the precursor molecule to thyrotrophin but the densely granulated subtypes stain more strongly (OSAMURA, KAJIYA, TAKEI et al., 2008; SAEGER, LÜDECKE, BUCHFELDER et al., 2007).

The silent corticotroph adenomas are usually macroadenomas and are more invasive in nature. Some secrete high molecular weight adrenocorticotrophic hormones (OSAMURA, KAJIYA, TAKEI et al., 2008). These subtypes are of two types, the densely and sparsely granulated, both of which are indistinguishable morphologically from their more active counterparts (OSAMURA, KAJIYA, TAKEI et al., 2008; SAEGER, LÜDECKE, BUCHFELDER et al., 2007). Crooke's cell adenomas are very rare and are the most aggressive of the corticotroph adenomas. They are characterized by cells with densely eosinophilic and hyaline cytoplasm, which is due to massive accumulation of intermediate filaments (OSAMURA, KAJIYA, TAKEI et al., 2008). The majority of these tumours are hyper-functioning and invasive (SAEGER, LÜDECKE, BUCHFELDER et al., 2007).

\subsection{Gonadotrophin family}

Gonadotrophic adenomas secrete both luteinising and follicle stimulating hormones ( $\mathrm{LH}$ and $\mathrm{FSH}$ ). These tumours usually arise in middle age and thus can be clinically difficult to diagnose (HINTON and ASA, 2009). In men, they often present as macroadenomas with compressive effects. The premenopausal raised gonadotrophin level in women confuses the picture and results in late presentation as macroadenomas (HINTON and ASA, 2009).

Most actively secreting gonadotroph adenomas secrete FSH with $\alpha$ or $\beta$ subunit. Some may secrete both LH and FSH but pure LH adenomas are rare. FSH adenomas are particularly more commonly found in men (OSAMURA, KAJIYA, TAKEI et al., 2008; HINTON and ASA, 2009). The silent tumours are usually macroadenomas and histologically indistinguishable from the active variant. The tumours are chromophobic and disposed in trabeculae and often form perivascular pseudorosettes with appearance resembling aesthesioneuroblastoma (OSAMURA, KAJIYA, TAKEI et al., 2008; HINTON and ASA, 2009; SAEGER, LÜDECKE, BUCHFELDER et al., 2007) (Figure 4).

Immunohistochemically the cells stain positively for $\mathrm{FSH}$ or LH and sometimes both (Figures 5 and 6). They also show positivity for $\alpha$ and $\beta$ subunits (HINTON and ASA, 2009). Occasionally some of the cells show oncocytic appearance with accumulation of mitochondria and are called oncocytomas.

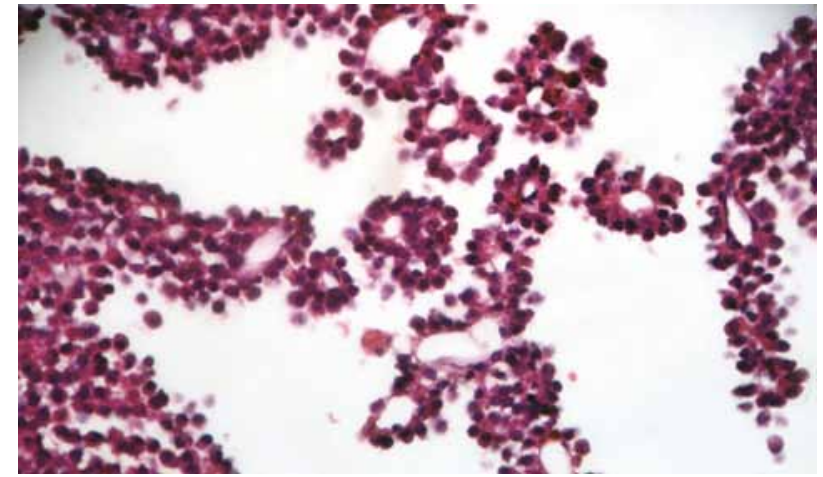

Figure 4. Rossete formation in a Pituitary adenoma. H and E.

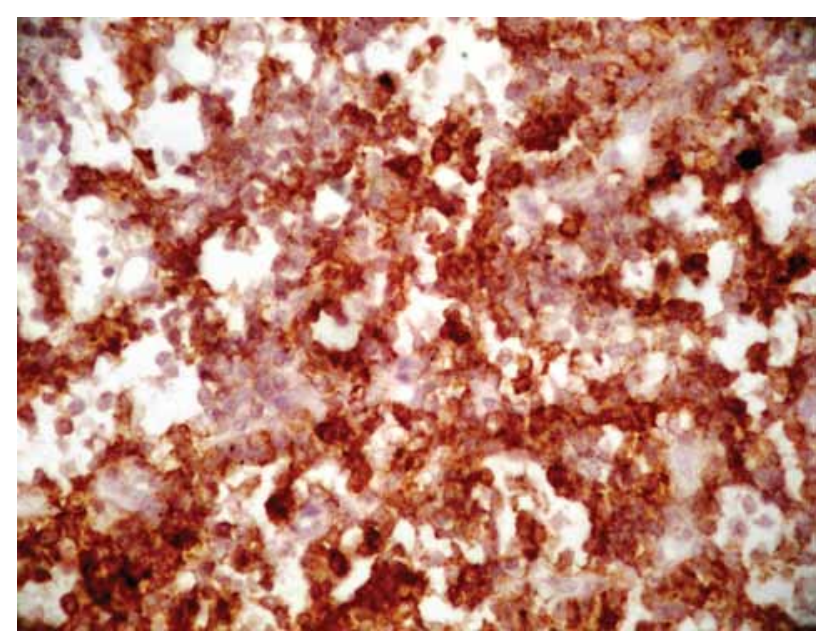

Figure 5. Immunohistochemical stain in a pituitary adenoma positive for Luteinising hormone.

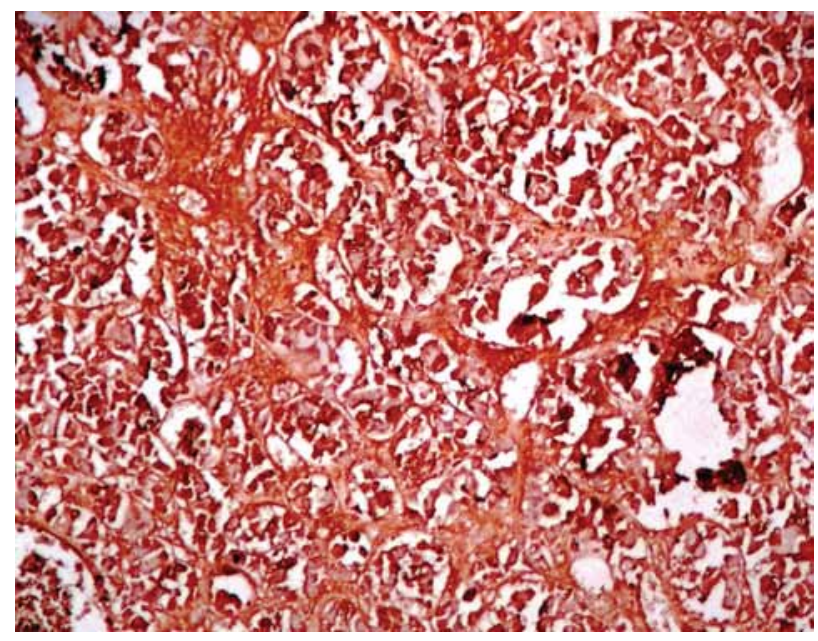

Figure 6. Immunohistochemical stain in a normal pituitary gland stained for Luteinising hormone.

Gonadotroph adenomas express the transcription factor SF1 (steroidogenic factor) to which they are specific (ASA and EZZAT, 1998; OSAMURA, KAJIYA, TAKEI et al., 2008). Many of the clinically silent gonadotrophic hormones show no reactivity for any of the pituitary hormones and are designated as null cell adenomas. They may secrete $\alpha$ subunit but not whole hormones and some of them also show oncocytic 
appearance (HINTON and ASA, 2009; SAEGER, LÜDECKE, BUCHFELDER et al., 2007).

\subsection{Pluribormonal adenomas}

Plurihormonal tumours can be either composed of one cell type secreting more than one hormone or several different functional cell types in the same tumour (SAEGER, LÜDECKE, BUCHFELDER et al., 2007). These tumours are divided into three subtypes. Subtype 1 adenomas express TSH, FSH, $\mathrm{LH}, \alpha$ subunit or prolactin in addition to growth hormone. Histologically and ultrastructurally, the cells appear more like the densely granulated subtype somatotroph adenomas (SAEGER, LÜDECKE, BUCHFELDER et al., 2007). The subtype 2 plurihormonal adenomas are structurally similar to gonadotrophic adenomas. They express either TSH or growth hormone or prolactin in addition to $\mathrm{FSH}, \mathrm{LH}$ and $\alpha$ subunit. Both type 1 and 2 show cells of different types in the adenomas with one cell type often predominating (SAEGER, LÜDECKE, BUCHFELDER et al., 2007).

The type 3 plurihormonal adenoma occurs more frequently than the other two and carries a poor prognosis. It is a silent tumour with higher frequency in women and often presents as macroadenomas (OSAMURA, KAJIYA, TAKEI et al., 2008; SAEGER, LÜDECKE, BUCHFELDER et al., 2007). These tumours show immunoreactivity for growth hormone, TSH and prolactin as well as several others. The tumour has a high recurrence rate and is invasive. It often presents with features of prolactinoma but does not respond to dopamine agonists (OSAMURA, KAJIYA, TAKEI et al., 2008; HINTON and ASA, 2009; SAEGER, LÜDECKE, BUCHFELDER et al., 2007). Histologically the tumour cells show nuclear pseudoinclusions and marked accumulation of rough and smooth endoplasmic reticulum.

\subsection{Null cell adenomas}

Null cell adenomas are not reactive or weakly reactive to any of the hypophyseal hormones. They are usually macroadenomas and present late because they are non-functional (OSAMURA, KAJIYA, TAKEI et al., 2008). These tumours often show similar morphological features to the gonadotroph adenomas and some have suggested that they arose from gonadotrophs (AL-BRAHIM and ASA, 2006; ASA and EZZAT, 1998; OSAMURA, KAJIYA, TAKEI et al., 2008; KLEINSCHMIDTDEMASTERS, 2011). They are chromophobic with moderate eosinophilic cytoplasm and characteristic pseudorosettes (OSAMURA, KAJIYA, TAKEI et al., 2008; SAEGER, LÜDECKE, BUCHFELDER et al., 2007).

\subsection{Atypical adenomas}

The WHO classification of 2004 includes atypical adenomas which are characterized by local invasion and increased mitosis (SAEGER, LÜDECKE, BUCHFELDER et al., 2007; LLOYD, SCHEITHAUER, HORVATH et al., 2009). The atypical adenomas usually show an increased MIB-1 labelling index of more than $3 \%$ and often show $\mathrm{p} 53$ reactivity which is not seen in benign tumours (IRONSIDE 2003; SAEGER, LÜDECKE, BUCHFELDER et al., 2007). Most cases of this variant of adenomas are sparsely granulated somatomammotrophs, sparsely granulated corticotrophs and null cell adenomas (SCHEITHAUER, KOVACS, LAWS JUNIOR et al., 1986; SAEGER, LÜDECKE, BUCHFELDER et al., 2007). The subtype 3 plurihormonal adenomas fall into these group of tumours and are classified as one of the atypical variants (SAEGER, LÜDECKE, BUCHFELDER et al., 2007). These tumours carry a poor prognosis due to their high recurrence rate (HSU, HAKIM, BILLER et al., 1993).

\subsection{Pituitary carcinoma}

Pituitary carcinomas are characterized by spread to distant sites either via the CSF or to extraneural sites (IRONSIDE, 2003; SAEGER, LÜDECKE, BUCHFELDER et al., 2007; LLOYD, SCHEITHAUER, HORVATH et al., 2009; OGILVY and JAKUBOWSKI, 1973). They are very rare and only about a hundred cases have been reported in literature (HINTON and ASA, 2009; SAEGER, LÜDECKE, BUCHFELDER et al., 2007). They are characterized by rapid growth and may show some atypia and cellular pleomorphism ${ }^{3}$. Invasive adenomas often form the precursors for pituitary carcinomas (SAEGER et al, 2007; OGILVY and JAKUBOWSKI, 1973). There is usually no necrosis or vascular proliferation. Pituitary carcinomas are usually functional and are most often corticotrophs or lactotrophs (ONTJES and NEY, 1976; SAEGER et al, 2007; LLOYD et al, 2009; OGILVY and JAKUBOWSKI, 1973).

Metastatic spread can affect the spine, liver, lung, bone and lymph nodes with corticotrophs more commonly showing extraneural spread (HINTON and ASA, 2009). There is often positivity for p53 staining and expression of TP53 with increased Ki 67 index (IRONSIDE, 2003; HINTON and ASA, 2009; SAEGER, LÜDECKE, BUCHFELDER et al., 2007; LLOYD et al, 2009). The prognosis for this tumour is poor (SAEGER, LÜDECKE, BUCHFELDER et al., 2007; WARREN-BARAN and PRAYSON, 2010).

\section{Conclusion}

In summary, pituitary adenomas are among the most frequent intracranial tumours and can present with over-expression of the hormones normally produced by the pituitary gland or pressure symptoms from the tumour. These tumours occur slightly more frequently in men with an age range of 30 years to 60 years. They are not common in children. Pituitary adenomas are clonal tumours and often show over-expression of tumour suppressor genes which can sometimes be familial.

Several subclasses exist and the presentation may be different depending on the particular hormone produced. The prolactinomas are the commonest type followed by the silent adenomas with Gonadotrophs and TSH producing adenomas constituting the rare types. Many pituitary adenomas produce more than one hormone. The silent adenomas are often aggressive and can grow to large sizes with infiltration of surrounding structures. Pituitary carcinomas are very rare and only occur when a tumour metastasizes irrespective of the degree of anaplasia.

\section{References}

AL-BRAHIM, NY. and ASA, SL. My approach to pathology of the pituitary gland. Journal of Clinical Pathology, 2006, December, vol. 59, n. 12, p. 1245-1253. http://dx.doi.org/10.1136/ jcp.2005.031187. PMid:17142570.

ASA, SL. and EZZAT, S. The cytogenesis and pathogenesis of pituitary adenomas. Endocrine Reviews, 1998, December, vol. 19, n. 6, p. 798-827. PMid:9861546. 
BECKERS, A. and DALY, AF. The clinical, pathological, and genetic features of familial isolated pituitary adenomas. European Journal of Endocrinology, 2007, October, vol. 157, n. 4, p. 371-382. http:// dx.doi.org/10.1530/EJE-07-0348. PMid:17893250.

BOIKOS, SA. and STRATAKIS, CA. Molecular genetics of the cAMP-dependent protein kinase pathway and of sporadic pituitary tumorigenesis. Human Molecular Genetics, 2007, vol. 16, n. Rl, p. $80-87$.

CAWICH, S., CRANDON, I., HARDING, H. and MCLENNON, $\mathrm{H}$. Clinical presentations of pituitary adenomas at a university hospital in Jamaica. The Internet Journal of Family Practice, 2008, vol. 7, n. 2. Available from: <http://www.ispub.com:80/journal/the-internetjournal-of-family-practice/volume-7-number- 2 /clinical-presentationsof-pituitary-adenomas-at-a-university-hospital-in-jamaica.html>.

COSTELLO, RT. Subclinical adenoma of the pituitary gland. American Journal of Pathology, 1936, March, vol. 12, n. 2, p. 205-216.1. PMid:19970261.

DALY, AF., TICHOMIROWA, MA. and BECKERS, A. The epidemiology and genetics of pituitary adenomas. Best Practice \& Research. Clinical Endocrinology \& Metabolism, 2009, October, vol. 23, n. 5, p. 543-554. http://dx.doi.org/10.1016/j. beem.2009.05.008. PMid:19945022.

EZZAT, S., ASA, SL., COULDWELL, WT., BARR, CE., DODGE, WE., VANCE, ML. and MCCUTCHEON, IE. The prevalence of pituitary adenomas: a systematic review. Cancer, 2004, August 1, vol. 101, n. 3, p. 613-619. http://dx.doi.org/10.1002/cncr.20412. PMid:15274075.

EZZAT, S. and ASA, SL. Mechanisms of disease: The pathogenesis of pituitary tumors. Nature Clinical Practice. Endocrinology \& Metabolism, 2006, April, vol. 2, n. 4, p. 220-230. http://dx.doi. org/10.1038/ncpendmet0159. PMid:16932287.

FARRELL, WE. Pituitary tumours: findings from whole genome analyses. Endocrine-Related Cancer, 2006, September., vol. 13, n. 3, p. 707-716. http://dx.doi.org/10.1677/erc.1.01131. PMid:16954426.

HEMMINKI, K., FÖRSTI, A. and JI, J. Incidence and familial risks in pituitary adenoma and associated tumors. Endocrine-Related Cancer, 2007, March, vol. 14, n. 1, p. 103-109. http://dx.doi. org/10.1677/ERC-06-0008. PMid:17395979.

HINTON, DR. and ASA, SL. Pituitary. In COTE, RJ., WEIDNER, N., SUSTER, S. and WEISS, LM. (Eds.). Modern Surgical Pathology, Philadelphia: Saunders Elsevier. 2009, p. 1949-1979.

HSU, DW., HAKIM, F., BILLER, BM., DE LA MONTE, S., ZERVAS, NT., KLIBANSKI, A. and HEDLEY-WHYTE, ET. Significance of proliferating cell nuclear antigen index in predicting pituitary adenoma recurrence. Journal of Neurosurgery, 1993, May, vol. 78, n. 5, p. 753-761. http://dx.doi.org/10.3171/jns.1993.78.5.0753. PMid:8096873.

IDOWU, O., AKANG, E. and MALOMO, A. Symptomatic primary intracranial neoplasms in Nigeria, West Africa. Journal of the Neurological Sciences, 2007, vol. 24, p. 212-218.

IGUN, GO. Diagnosis and management of brain tumours at Jos University Teaching Hospital, Nigeria. East African Medical Journal, 2001, March, vol. 78, n. 3, p. 148-151. http://dx.doi.org/10.4314/ eamj.v78i3.9082. PMid:12002056.

IRONSIDE, JW. Pituitary gland pathology. Journal of Clinical Pathology, 2003, August, vol. 56, n. 8, p. 561-568. http://dx.doi. org/10.1136/jcp.56.8.561. PMid:12890801.

KLEINSCHMIDT-DEMASTERS, BK. Pituitary Gland. In ROSAI, J. (Ed.) Rosai and Ackerman's Surgical Pathology. 10th ed. Edinburgh: Elsevier; 2011. p. 2441-2459.

KOVACS, K., HORVATH, E., STEFANEANU, L., BILBAO, J., SINGER, W., MULLER, PJ., THAPAR, K. and STONE, E. Pituitary adenoma producing growth hormone and adrenocorticotropin: a histological, immunocytochemical, electron microscopic, and in situ hybridization study. Case report. Journal of Neurosurgery, 1998, June, vol. 88, n. 6, p. 1111-1115. http://dx.doi.org/10.3171/ jns.1998.88.6.1111. PMid:9609310.

KOVACS, K., HORVATH, E. and VIDAL, S. Classification of pituitary adenomas. Journal of Neuro-Oncology, 2001, September, vol. 54, n. 2, p. 121-127. http://dx.doi.org/10.1023/A:1012945129981. PMid:11761429.

KUNWAR, S. and WILSON, CB. Pediatric pituitary adenomas. The Journal of Clinical Endocrinology and Metabolism, 1999, December., vol. 84, n. 12, p. 4385-4389. http://dx.doi.org/10.1210/ jcem.84.12.6240. PMid:10599692.

LAFFERTY, AR. and CHROUSOS, GP. Pituitary tumors in children and adolescents. The Journal of Clinical Endocrinology and Metabolism, 1999, December, vol. 84, n. 12, p. 4317-4323. http:// dx.doi.org/10.1210/jcem.84.12.6215. PMid:10599681.

LANIA, A., MANTOVANI, G. and SPADA, A. Genetics of pituitary tumors: focus on G-protein mutations. Experimental Biology and Medicine, 2003, October, vol. 228, n. 9, p. 1004-1017. PMid:14530508.

LEVY, A. Pituitary disease: presentation, diagnosis, and management. Journal of Neurology, Neurosurgery, and Psychiatry, 2004, September., vol. 75, sup. Suppl 3, p. iii47-iii52. http://dx.doi. org/10.1136/jnnp.2004.045740. PMid:15316045.

LLOYD, RV., KOVACS, K., YOUNG JUNIOR, WF., FARRELL, WE., ASA, SL., TROUILIAS, J., KONTOGEORGO, G., SANO, T., SCHEITHAUER, BW. and HORVATH, E. Pituitary tumours. In LLOYD, RV., DELLELIS, RA., HEITZ, PU. and ENG, C. (Eds). Pathology and genetics of tumours of endocrine glands. New York: IARC press, 2004. p. 9-45.

LLOYD, RV., SCHEITHAUER, BW., HORVATH, E. and KOVACS, K. Tumors of the Pituitary gland. In KHAN, A. (Eds). Surgical pathology of endocrine and neuroendocrine tumours. New York: Humana Press, 2009. p. 27-40.

LOPES, MBS., PERNICONE, PJ., SCHEITHAUER, BW., HORVATH, E. and KOVACS, K. Pituitary and sellar region. In MILLS, SE. (Ed.). Histology for pathologists. Philadelphia: Lippincott Williams \& Wilkins, 2007. p. 322-344.

MAITRA, A. The Endocrine System. In KUMAR, V., ABBAS, AK., FAUSTO, N. and ASTER, JC. (Eds.). Robbins and Cotran pathologic basis of disease. Philadelphia: Saunders Elsevier, 2010. p. 1098-1107.

MELMED, S. Clinical Perspective: acromegaly and cancer: not a problem? The Journal of Clinical Endocrinology and Metabolism, 2001, July., vol. 86, n. 7, p. 2929-2934. http://dx.doi.org/10.1210/ jcem.86.7.7635. PMid:11443145.

MELMED, S. Update in pituitary disease. The Journal of Clinical Endocrinology and Metabolism, 2008, February., vol. 93, n. 2, p. 331-338. http://dx.doi.org/10.1210/jc.2007-1409. PMid:18258780.

NOSÉ, V. and HEDLEY-WHITE, ET. Diseases of the pituitary gland. In POIRIER, J., GRAY, F. and DE GIROLAMI, U. (Eds.). Escourolle \& Poirier manual of basic neuropathology. Philadelphia: Butterworth-Heinemann, 2004. p. 345-364.

OGILVY, KM. and JAKUBOWSKI, J. Intracranial dissemination of pituitary adenomas. Journal of Neurology, Neurosurgery, and Psychiatry, 1973, April, vol. 36, n. 2, p. 199-205. http://dx.doi. org/10.1136/jnnp.36.2.199. PMid:4708454.

OHAEGBULAM, SC., SADDEQI, N. and IKERIONWU, S. Intracranial tumors in Enugu, Nigeria. Cancer, 1980, November 15, vol. 46, n. 10, p. 2322-2324. http://dx.doi.org/10.1002/10970142(19801115)46:10<2322::AID-CNCR2820461034>3.0.CO;2-F. PMid:7427874. 
OLASODE, BJ., SHOKUNBI, MT. and AGHADIUNO, PU. Intracranial neoplasms in Ibadan, Nigeria. East African Medical Journal, 2000, January, vol. 77, n. 1, p. 4-8. PMid:10944829.

ONTJES, DA. and NEY, RL. Pituitary tumors. CA: a Cancer Journal for Clinicians, 1976, November-December, vol. 26, n. 6, p. 330350. http://dx.doi.org/10.3322/canjclin.26.6.330. PMid:186163.

OSAMURA, RY., KAJIYA, H., TAKEI, M., EGASHIRA, N., TOBITA, M., TAKEKOSHI, S. and TERAMOTO, A. Pathology of the human pituitary adenomas. Histochemistry and Cell Biology, 2008, September, vol. 130, n. 3, p. 495-507. http://dx.doi.org/10.1007/ s00418-008-0472-1. PMid:18688636.

REMICK, AK., WOOD, CE., CANN, JA., GEE, MK., FEISTE, EA., KOCK, ND. and CLINE, JM. Histologic and immunohistochemical characterization of spontaneous pituitary adenomas in fourteen cynomolgus macaques (Macaca fascicularis). Veterinary Pathology, 2006, July, vol. 43, n. 4, p. 484-493. http://dx.doi.org/10.1354/ vp.43-4-484. PMid:16846990.

SAEGER, W., LÜDECKE, DK., BUCHFELDER, M., FAHLBUSCH, R., QUABBE, HJ. and PETERSENN, S. Pathohistological classification of pituitary tumors: 10 years of experience with the German Pituitary Tumor Registry. European Journal of Endocrinology, 2007, February, vol. 156, n. 2, p. 203-216. http://dx.doi.org/10.1530/ eje.1.02326. PMid:17287410.

SALEHI, F., KOVACS, K., SCHEITHAUER, BW., CANTELMI, D., HORVATH, E., LLOYD, RV. and CUSIMANO, M. Immunohistochemical expression of pituitary tumor transforming gene (PTTG) in pituitary adenomas: a correlative study of tumor subtypes. International Journal of Surgical Pathology, 2010, February, vol. 18, n. 1, p. 5-13. http://dx.doi.org/10.1177/1066896909356105. PMid:20106827.
SCHEITHAUER, BW., KOVACS, KT., LAWS JUNIOR, ER and RANDALL, RV. Pathology of invasive pituitary tumors with special reference to functional classification. Journal of Neurosurgery, 1986, December., vol. 65, n. 6, p. 733-744. http://dx.doi.org/10.3171/ jns.1986.65.6.0733. PMid:3095506.

SCHEITHAUER, BW. Pituitary tumours and related lesions. In NELSON, JS., MENA, H., PARISI, JE. and SCHOCHET JUNIOR, SS. (Eds). Principles and practice of neuropathology. 2 nd ed. New York: Oxford University Press, 2003. p. 396-419.

SINGH, SK. and AGGARWAL, R. Pituitary adenomas in childhood. Indian Journal of Pediatrics, 2005, July, vol. 72, n. 7, p. 583-591. http://dx.doi.org/10.1007/BF02724183. PMid:16077242.

VANDEVA, S., JAFFRAIN-REA, ML., DALY, AF., TICHOMIROWA, M., ZACHARIEVA, S. and BECKERS, A. The genetics of pituitary adenomas. Best Practice \& Research. Clinical Endocrinology \& Metabolism, 2010, June, vol. 24, n. 3, p. 461-476. http://dx.doi. org/10.1016/j.beem.2010.03.001. PMid:20833337.

WARREN-BARAN, CB. and PRAYSON, RA. Nonneoplastic and neoplastic pituitary diseases. In HUNT, JL., (Ed). Molecular pathology of endocrine diseases. New York: Springer, 2010. p. 175-189.

WEN-QING, H., SHI-JU, Z., QING-SHENG, T., JIAN-QING, H., YU-XIA, L., QING-ZHONG, X., ZI-JUN, L. and WEN-CUI, Z. Statistical analysis of central nervous system tumors in China. Journal of Neurosurgery, 1982, April., vol. 56, n. 4, p. 555-564. http://dx.doi.org/10.3171/jns.1982.56.4.0555. PMid:7062128.

Received March 18, 2014 Accepted July 8, 2015 